\title{
Research on Blended Teaching Model in College English Based on Moso Teach Platform
}

\author{
Hang Dai \\ Foreign Language Department, Qiqihar Medical University, Qiqihar,161006, China
}

Keywords: Blended Teaching Model, College English, Moso Teach Platform

\begin{abstract}
In recent years, with the popularity of mobile terminals and the development of mobile learning, the teaching concept, teaching model and teaching tool of college teachers have undergone tremendous changes. Blended teaching model combines the dual advantages of autonomous learning and classroom teaching, and has become one of the most competitive teaching models today. Based on Moso Teach platform, this paper expounds the design methods of the blended teaching model of College English. Practice has proved that the blended teaching model of College English teaching based on the Moso Teach platform can achieve good teaching results.
\end{abstract}

\section{Concept and Features of Blended Teaching Model}

The blended teaching is formally a mixture of autonomous learning (including distance learning, network learning, group learning and other student's active learning behavior) and classroom learning (teacher's teaching, integrated teaching and blackboard teaching) [1]. Its essence is a mixture of teaching elements including teaching process, teaching links, teaching methods, teaching design, learning methods, learning environment, learning resources, learning mode, learning support and so on. At the right time, through the appropriate technology and appropriate style to combine a variety of teaching forms, the goal is to enable students to improve learning efficiency, improve learning ability, broaden learning resources to achieve the best learning results. Mixed teaching is not simply to all teaching forms and learning elements together, but to choose the form, mode and elements of organic integration. Therefore, the teaching design of blended teaching is particularly important. According to different teaching process, curriculum content should be targeted to achieve the desired teaching effect.

\section{Blended Teaching Model}

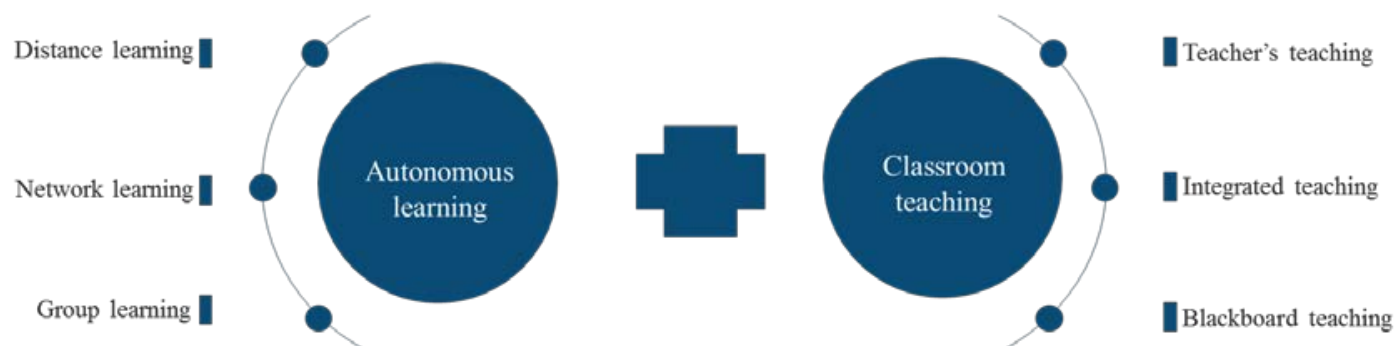

Figure 1. Concept figure of blended teaching model

Compared with traditional teaching, blended teaching has the following characteristics. Teaching runs throughout the whole of process student's learning, which is not restricted by the space and time in the traditional classroom. Instructional design is more systematic, and efforts are made to solve the problem of disconnection between teaching objectives and practical teaching. The blended teaching mode is more flexible, highlighting the development of students' personality and the cultivation of autonomous learning ability. Integrating teaching and learning, teachers and students establish a good interaction mechanism. To improve teaching, we should timely manage teaching and diagnose teaching in time. Blended teaching realizes digital teaching, intelligently manages the whole process 
of students' learning, and changes the way of teaching evaluation. In the current higher education, many teachers try various online platforms to carry out online learning activities. But the current network teaching platform has some shortcomings, cannot adapt to the current trend of mobile learning, and cannot effectively combine classroom teaching and after-class learning. Most of the current network teaching platform cannot timely feedback test results, cannot follow up the progress of student learning and so on. Under such circumstances, it is difficult to achieve the timeliness and synchronization of mixed teaching, and the effect of mixed learning is not obvious. As a practical language course, some of the College English courses can be reversed. College English teachers can use Moso Teach for online learning or mixed teaching [2].

\section{Summary of Moso Teach Platform}

Moso Teach is a client based on mobile internet to meet the needs of teachers and students both inside and outside the classroom, and to provide instant feedback on teaching interaction [3]. It helps teachers improve their interaction with students and motivates students to learn on mobile devices. Unlike social tools, Moso Teach can provide students with a pure mobile learning and communication environment, so that student mobile phones become a learning tool, to a certain extent, to stimulate students' interest in using mobile phones for autonomous learning. Teachers should selectively use the tools in cloud classes, and use questions, cooperation, exercises, tests and other methods to mobilize the enthusiasm of students, so that students can participate in classroom activities. Teachers should rely on the content and charm of the lecture to attract students, and cannot blindly complain that students do not listen carefully. Teachers in the classroom teaching content is novel, with the teacher's unique perspective of observation, so that students have a fresh sense of teaching content. In the mobile era, the role of teachers and students has changed with the help of the Moso Teach platform. Teachers are no longer simply teaching knowledge through the classroom, students can only passively accept, but through the pre-class, during and after class, give full play to the enthusiasm and initiative of students, teaching to achieve integration. Teachers can easily manage their classes, manage students, send notifications, share resources, assign corrective assignments, organize discussion and answer questions, and carry out teaching interaction. In any ordinary classroom, teachers can immediately carry out voting questionnaires, brainstorming and other interactive teaching activities, immediate feedback and immediate comments. All course content that teachers need to send to students can be delivered to students instantly through mobile terminals, so that mobile devices become learning tools, not just social and game. At the same time, the Moso Teach mobile interactive digital teaching materials can track and evaluate the progress and effectiveness of each student's learning. By the end of the course, the teachers can easily get the evaluation report of each student's learning [4].

\section{Applicaitons of Moso Teach Platform in Blended Teaching Model of College English}

\subsection{Blended Teaching Part before Class}

Before the class begins, teachers can assign pre-class tasks and publish relevant micro-courseware and other teaching resources in the resource module. Teachers use the notification module to list the learning tasks, and ask students to complete self-study or preview within a certain period. Sometimes, teachers can also use the activity module assignments and group assignments, or use the test function to check the student's pre-class task mastery. Before class, teachers can also add activities in advance, but not release them, and release them immediately when they need to use them in class to improve classroom efficiency. English teachers design teaching in advance, create scenarios by publishing resources, setting up problems, brainstorming and other activities, stimulate student's interest in learning, and guide students to learn English independently. In the process of self-study, students can use the Moso Teach to discuss problems. Teachers can determine the next step of teaching objectives according to the problems raised by students, design teaching content, and prepare for effective classroom teaching. Therefore, pre-class learning is no longer blind preview of students, but under the 
supervision of teachers, autonomous learning can gradually improve student's autonomous learning ability. Through the Internet search, the author selected an English video with the theme of "telephone call" on the video website for self-study before class. Teachers only need to copy the video link in the client, and then paste it in the Moso Teach resource interface, then they can publish the video learning materials to the whole class in time. The whole process can only be completed successfully on the mobile phone end, which is very convenient. In addition to Publishing Web links, Moso Teach can also publish micro-lessons, PPT, exercises and other commonly used learning materials, providing convenient conditions for self-study links before the flipped class.

\subsection{Blended Teaching Part during Class}

Moso Teach operation is very convenient, which can launch a lot of activities at any time. For example, teachers can start sign in function in one minute or even dozens of seconds. Data can be analyzed at any time, and we can see clearly the rate of each student coming to class. In College English classroom, traditional classroom questioning can only mention a few students, it is difficult to understand the grasp of most students. Traditional classroom teachers can only hear a small number of student's oral tasks, and make good use of the "homework" function, so that each student can submit their answers, or group oral dialogue, so that students can submit oral audio, teachers can carefully evaluate after class, a good understanding of students' learning. Examination of pre-class tasks can also be initiated at the beginning of the class, a ready test activity, or a phased test after a phase. The automatic scoring system greatly improves the teaching effect, and greatly saves the teacher's correcting homework. It can also explain the problems with high error rate according to the analysis after the test. In class, teachers can use cloud platform to enrich classroom teaching. For example, by organizing brainstorming activities on the cloud platform to ensure that all students can participate in the discussion, this can promote introverted students to participate in the classroom, improve student's interest in learning. After class, teachers use the cloud platform to arrange homework, and students upload their homework to the cloud platform, then they can conduct anonymous mutual evaluation. This way, on the one hand, students can be urged to complete their homework better, on the other hand, it also increases the relevance and interaction between students. Teachers can see students' learning progress and resource view in class. At the end of the semester, English teachers can get a report of each student's learning assessment, and make a relatively objective assessment of the student's procedural learning. At the same time, according to the assessment report, they can give guidance to the students.

\subsection{Blended Teaching Part after Class}

At the beginning of a course, after-school teachers can get teaching feedback by "voting/questionnaires". Teachers can design a few simple questions for students to vote, then they can know the student's feelings and reactions in some aspects, and then adjust their teaching activities accordingly, or give students some guidance. With the help of Moso Teach, homework after class has become more efficient and convenient. The objective question is to use the test function, and the subjective task is to use the task / group task function. Most homework students have mobile phones, they can forget the traditional homework books, and teachers do not have to carry thick stacks of homework books into the office. And through the resources section, teacher's courseware teaching content, students can repeatedly watch review, internalized into their own things, review process is more convenient and faster. Now the network learning resources are also rich and varied, but weak discrimination, teachers can carefully select the appropriate resources, links published in the resources, to recommend fewer and refined supplementary learning materials to students, these are after-school can assist students in learning part. In the Moso Teach, teachers can also publish a "discussion / answer" activity for students to ask and answer questions after class. After class, teachers increase practice opportunities through knowledge point tests and assignment tasks to consolidate and expand the content they have learned; through off-line answers, questionnaires, homework corrections, learning evaluation and summary activities, teachers accurately grasp teaching problems, conduct after-class reflection, adjust and improve the follow-up teaching. According to the learning data, Moso Teach intelligently analyzes and provides teachers with 
teaching reports to help them diagnose teaching in time. In addition, teachers can effectively manage attendance, classroom performance and learning process performance with the help of Moso Teach, and record them in digital form, to collect the results of process evaluation and summative evaluation. Teachers can also publish curriculum packages according to their own curriculum resources, assignments and activities.

\section{Teaching Results Analysis Blended Teaching Model in College English}

The author has carried out the practice of blended teaching of College English based on Moso Teach platform for students in Qiqihar Medical University. The Moso Teach improves the effect of classroom teaching and facilitates the whole teaching process of College English. Now the college attaches great importance to the management of the student's teaching process. The whole semester of teaching activities has been recorded, the process management records clear and objective, each student's learning process records can be derived. Although the classroom teaching evaluation system has only been put into use for less than four months, the number of students with poor learning effect is obviously reduced, which shows that the mobile terminal-based computer classroom teaching evaluation system is feasible and effective. From the survey data, after the use of the evaluation system, the number of people who like the teaching methods of teachers has increased significantly, and the effect of the guidance to students has been doubled, especially the participation of students in the classroom has greatly improved. In addition, with the help of cloud platform, layered teaching can be achieved to a certain extent. Each class has different English proficiency, so classroom teaching can only be based about most students. After class, we use cloud class to build different class resources according to the different levels of students' listening ability. This can make up for the lack of classroom teaching. In the process of learning, students are constantly given feedback evaluation, which effectively changes the phenomenon that evaluation only pays attention to the results, gives full play to the developmental function of evaluation, and improves the evaluation effect. Teachers should pay more attention to the progress and subtle changes in the process of learning, and make good use of mobile teaching evaluation system to record classroom performance in time. Through the mobile terminal, teachers can understand the learning situation in an all-round way at any time, and can also grasp the students' individual learning situation in time, providing reliable evidence for classroom teaching.

\section{Conclusion}

Blended teaching breaks the teacher-centered teaching model and gives full play to the student dominant position in the learning process. It combines the advantages of traditional teaching model and greatly improves students' enthusiasm and efficiency of autonomous learning. The blended teaching design based on Moso Teach platform can optimize college English teaching and achieve good teaching results.

\section{Acknowledgment}

The Teaching Research Project of Qiqihar Medical University in 2018 Titled "Research on the Blended Teaching Mode of College English based on Mosoteach Platform"(Project Number: QYJY20180108).

\section{References}

[1] Liu Min. The Application of Blended Teaching in College English Listening Courses Based on Blue moyun Class [J]. The Guide of Science \& Education, 2017, 25(9): 78-79.

[2] Li Dongming. On the Construction and Implementation of a Mode of Blended Learning Based on Moso Teach [J]. Journal of Beijing Polytechnic College, 2018, 17(2): 90-95. 
[3] Tan Chunlan. Educational Reform Practice of Flipped Classroom Based on Moso Teach [J]. Logistics Engineering and Management, 2016, 38(6): 219-220+240.

[4] Li Fengqing. The Theoretical Basis and Instructional Design of Blending Teaching [J]. Modern Educational Technology, 2016, 26(9):18- 24. 